Info Artikel:

Diterima: 09/03/2017_Direvisi: 20/03/2017_ Dipublikasikan: 15/06/2017

\title{
Kajian Al-Maidah Ayat 64-71 Tentang Pendidikan: Metode Kisah Dan Gaya Komunikasi Dalam Pendidikan Islam
}

\author{
Wahyudin Noor, M.S.I
}

IAIN Syaikh Abdurrahman Siddik Bangka Belitung

\begin{abstract}
Surat al-Maidah: 64-71 tells two important things: first, the story of the Jews who were cursed by Allah because of bad speech born from envy and hatred against Prophet Muhammad SAW. Second, the obligation of Prophet Muhammad SAW in conveying Islam. These two things, if attributed to the context of Islamic education, will imply the existence of messages of Islamic education; the message of an educational method that is the method of story in one side, and on the other side describes the instructions of communication.
\end{abstract}

Keywords: Al-Maidah, Metode Kisah, Komunikasi, Pendidikan Islam

\section{PENDAHULUAN}

Ada hal menarik yang dapat dijadikan acuan dalam beberapa dasawarsa terakhir, yakni suatu kecenderungan positif yang tampak di kalangan masyarakat dewasa ini adalah pengkajian ayatayat al-Qur'an untuk menemukan kedalaman maknanya. Pengkajian itu tidak terbatas pada masalah keagamaan yang dogmatis saja, tetapi juga masalah sosial, budaya, politik, ekonomi maupun pendidikan.

Kesadaran ini, Al-Qur'an setidaknya harus dipandang sebagai panutan dalam berbagai aspek kehidupan, tidak hanya mencakup ajaran dogmatis, tetapi juga ilmu pengetahuan, dan salah satu cabang ilmu pengetahuan itu adalah ilmu pendidikan. Meskipun al-Qur'an tidak menjelaskan 
secara terinci tentang bagaimana esensi pendidikan, namun ada berbagai patokan dasar yang telah digariskannya.

Pendidikan adalah upaya penyampaian konsep atau ide kepada peserta didik agar peserta didik yang belum tahu menjadi tahu. Pengertian pendidikan ini merupakan pewarisan kebudayaan. ${ }^{1}$ Manusia yang akan dididik bagaikan alam kecil (mikrokosmos) yang penuh dengan bermacam-macam kekayaan. Dengan kata lain bahwa manusia bagaikan perut bumi yang penuh dengan barang tambang seperti emas, perak, intan, dan berlian. Kekayaan terpendam itu belum berguna sebelum ia diangkat dari perut bumi. Ia harus diangkat dan digali serta digarap untuk mengeluarkan kekayaan tersebut. Begitu halnya dengan manusia, dalam dirinya tersimpan banyak potensi yang bila dieksploitasi dengan cermat akan menjadi manusia yang professional yang berguna bagi diri dan masyarakatnya.

Peserta didik adalah raw input (bahan mentah) yang siap untuk diproses dalam lingkungan transformasi pendidikan untuk mencapai output tujuan pendidikan yaitu perubahan sikap. Bukankah sains dan teknologi itu adalah hasil kecerdasan dan kreatifitas manusia? Karena mengeksploitasi potensi-potensi manusia adalah tugas pendidikan dalam bentuk proses pembelajaran. Dengan demikian, pendidikan adalah suatu upaya transformasi nilai dan pengembangan potensi manusia.

Dasar pemikiran yang menggambarkan harapan atau tujuan setiap bentuk pendidikan dan makna mengenai esensi kependidikan tersebut sejalan dengan tujuan Al-Qur'an, yakni mengadakan perubahan-perubahan positif. Dasar pemikiran ini dijelaskan dalam surat Ibrahim ayat 1 berbunyi: Alif, laam raa, (ini adalah) Kitab yang Kami turunkan kepadamu supaya kamu mengeluarkan manusia dari gelap gulita kepada cahaya terang benderang dengan izin Tuhan mereka, (yaitu) menuju jalan Tuhan Yang Maha Perkasa Lagi Maha Terpuji. ${ }^{2}$

Berbagai teori pendidikan yang dihasilkan oleh para pakar ilmu pendidikan telah disepakati bahwa materi pendidikan harus disampaikan dengan metode dan gaya komunikasi yang baik. Metode dan juga komunikasi memiliki peran yang tidak kecil dalam pencapain sebuah tujuan pendidikan. Melalui metode, proses pendidikan menjadi lebih mudah. Dengan gaya komunikasi yang baik, proses pendidikan menjadi lebih efektif. Dengan demikian, pendidikan adalah suatu peristiwa penyampaian atau proses transformasi materi, baik kognitif, afektif dan psikomotorik, yang dilakukan dengan bantuan metode, serta gaya komunikasi yang efektif.

Untuk itu, dalam mengungkap akan pentingnya pemahaman mengenai metode dan gaya komunikasi tersebut, maka diperlukan adanya penelusuran pengetahuan dan pemahaman yang komprehensif dan mendalam yang tersaji di dalam Al-Qur'an, terutama terkait dengan metode dan gaya komunikasi dalamAl-Qur'an. Dan penulis merasa berkepentingan untuk menyajikan metode dan gaya komunikasi ini sebagai hasil pembacaan dari Al-Qur'an surat al-Maidah, terutama ayat 64-71.

Surat Al-Maidah dalam perspektif tafsir memiliki makna, yakni hidangan, karena dalam rangkaian ayat-ayatnya terdapat uraian tentang hidangan yang diturunkan atas permintaan Ahli Kitab. Nama lainnya adalah surat $A l-U q u d$ (akad-akad perjanjian), karena ayat pertama surat ini memerintahkan kaum beriman agar memenuhi ketentuan aneka akad yang dilakukan. Dia juga dinamai surat Al-Akhyar (Orang-orang baik), karena yang memenuhi tuntunannya menyangkut

\footnotetext{
${ }^{1}$ Hasan Langgulung, Tujuan Pendidikan dalam Islam, (Jakarta: Diktat Fakultas PPs IAIN Syarif Hidayatullah, Jakarta, t.t), h. 2

${ }^{2}$ Depag RI, Al-Qur'an dan Tafsirnya, Jilid 2 Juz 4,5,6 (Jakarta: Depag RI, 2009), Cet. III, h. 
ikatan perjanjian pastilah orang baik. Surat ini dinamai juga surat Al-Munqidzah (penyelamat), karena ia menyelamatkan pembaca dan pengamal tuntunannya dari malaikat penyiksa. ${ }^{3}$

Adapun karena keterbatasan penyajian, metode yang penulis paparkan di makalah ini adalah hanya metode kisah, mengingat hasil pembedahan surat al-Maidah ayat 64-71 hanya terkait metode kisah an sich, di samping gaya komunikasi dalam pendidikan Islam pun turut pula dipaparkan. Kemudian untuk pembahasan makalah ini, penulis membaginya dalam beberapa sub pembahasan, meliputi materi surat al-Maidah ayat 64-71, analisis tafsir dan analisis pendidikan.

\section{METODE}

Metode yang digunakan penulis adalah metode kisah, mengingat hasil pembedahan surat AlMaidah ayat 64-71 hanya terkait metode kisah an sich, di samping gaya komunikasi dalam pendidikan Islam pun turut pula dipaparkan.

\section{PEMBAHASAN}

\section{Materi Surat Al-Maidah ayat 64-71}

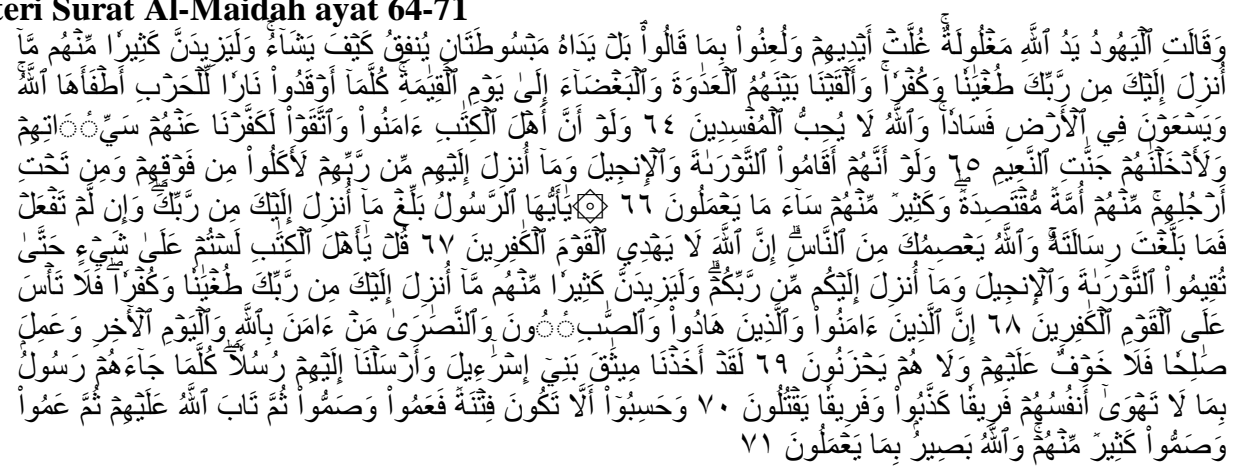

Artinya :

64. Orang-orang Yahudi berkata: "Tangan Allah terbelenggu", sebenarnya tangan merekalah yang dibelenggu dan merekalah yang dila'nat disebabkan apa yang telah mereka katakan itu. (tidak demikian), tetapi kedua-dua tangan Allah terbuka; Dia menafkahkan sebagaimana Dia kehendaki. Dan Al-Qur'an yang diturunkan kepadamu dari Tuhanmu sungguh-sungguh akan menambah kedurhakaan dan kekafiran bagi kebanyakan di antara mereka. dan Kami telah timbulkan permusuhan dan kebencian di antara mereka sampai hari kiamat. Setiap mereka menyalakan api peperangan Allah memadamkannya dan mereka berbuat kerusakan dimuka bumi dan Allah tidak menyukai orang-orang yang membuat kerusakan.

65. Dan sekiranya ahli kitab beriman dan bertakwa, tentulah Kami tutup (hapus) kesalahankesalahan mereka dan tentulah Kami masukkan mereka kedalam surga-surga yang penuh kenikmatan.

66. Dan sekiranya mereka sungguh-sungguh menjalankan (hukum) Taurat dan Injil dan (AlQur'an) yang diturunkan kepada mereka dari Tuhannya, niscaya mereka akan mendapat makanan dari atas dan dari bawah kaki mereka. Diantara mereka ada golongan yang pertengahan. Dan alangkah buruknya apa yang dikerjakan oleh kebanyakan mereka.

67. Hai Rasul, sampaikanlah apa yang diturunkan kepadamu dari Tuhanmu. Dan jika tidak kamu kerjakan (apa yang diperintahkan itu, berarti) kamu tidak menyampaikan amanat-Nya. Allah memelihara kamu dari (gangguan) manusia. Sesungguhnya Allah tidak memberi petunjuk kepada orang-orang yang kafir.

68. Katakanlah: "Hai ahli Kitab, kamu tidak dipandang beragama sedikitpun hingga kamu menegakkan ajaran-ajaran Taurat, Injil, dan Al-Qur'an yang diturunkan kepadamu dari

${ }^{3}$ Muhammad Quraish Shihab, Tafsir al-Misbah; Pesan, Kesan dan Keserasian al-Qur'an, Vol. 3, (Jakarta: Lentera Hati, 2002), Cet. III, h. 3 
Tuhanmu". Sesungguhnya apa yang diturunkan kepadamu (Muhammad) dari Tuhanmu akan menambah kedurhakaan dan kekafiran kepada kebanyakan dari mereka; Maka janganlah kamu bersedih hati terhadap orang-orang yang kafir itu.

69. Sesungguhnya orang-orang Mukmin, orang-orang Yahudi, Shabiin dan orang-orang Nasrani, siapa saja (diantara mereka) yang benar-benar saleh, Maka tidak ada kekhawatiran terhadap mereka dan tidak (pula) mereka bersedih hati.

70. Sesungguhnya Kami telah mengambil Perjanjian dari Bani Israil, dan telah Kami utus kepada mereka rasul-rasul. Tetapi setiap datang seorang Rasul kepada mereka dengan membawa apa yang yang tidak diingini oleh hawa nafsu mereka, (maka) sebagian dari Rasul-rasul itu mereka dustakan dan sebagian yang lain mereka bunuh.

71. Dan mereka mengira bahwa tidak akan terjadi suatu bencana pun (terhadap mereka dengan membunuh nabi-nabi itu), maka (karena itu) mereka menjadi buta dan pekak, kemudian Allah menerima taubat mereka, kemudian kebanyakan dari mereka buta dan tuli (lagi). Dan Allah Maha melihat apa yang mereka kerjakan.

\section{Analisis Tafsir}

Ayat 64, menurut riwayat Ibnu Ishak dan at-Tabrani dari Ibnu Abbas, dia berkata, "Seorang Yahudi yang bernama Nabbasy bin Qais berkata kepada Nabi Muhammad SAW, 'Tuhan engkau kikir, tidak suka memberi." Maka ayat ini meskipun yang mengatakan kepada Nabi itu hanya seorang dari kalangan Yahudi, namun dapat dianggap menggambarkan pendirian secara keseluruhan dari kaumnya. Ayat ini menceritakan bahwa orang Yahudi itu berkata, "Tangan Allah terbelenggu," tetapi yang sebenarnya terbelenggu adalah tangan mereka sendiri, dengan demikian mereka akan dilaknat Allah.

Perkataan orang Yahudi bahwa "tangan Allah terbelenggu" adalah tidak masuk akal, sebab mereka mengakui bahwa Allah adalah nama bagi zat yang pasti ada dan Mahakuasa, Dia pencipta alam semesta. Hal ini menunjukkan bahwa tangan Allah tidak terbelenggu dari kekuasaan-Nya yang tidak terbatas, karena jika demikian, maka tentulah Dia tidak dapat memelihara dan mengatur alam ini. Maka apakah yang mendorong mereka mengucapkan kata-kata demikian? Sebagian mufasir mengatakan bahwa dorongan tersebut adalah : 1). Mungkin mereka mendengar ayat : "Barangsiapa meminjami Allah dengan pinjaman yang baik maka Allah akan melipatgandakan ganti kepadanya dengan banyak. Allah menahan dan melapangkan (rezeki) dan kepada-Nyalah kamu dikembalikan". Setelah mendengar ayat ini, mereka mengatakan bahwa tangan Allah itu terbelenggu dengan arti kikir, karena Allah tidak mampu dan miskin sehingga memerlukan pinjaman. 2). Mereka mengucapkan ucapan tersebut dengan mengejek kaum Muslimin ketika mereka melihat sahabat Nabi yang sedang berada dalam kesempitan dan kesulitan. 3). Pada awalnya masyarakat Yahudi adalah orang-orang kaya. Ketika Nabi Muhammad diutus menjadi Rasul mereka menentan Allah, oleh karenanya mereka banyak mengeluarkan harta benda untuk menggagalkan dakwah sehingga orang-orang kaya dari kalangan mereka banyak yang menjadi miskin. Karena Allah tidak melapangkan rezeki lagi bagi mereka yang telah miskin itu, mereka mengeluarkan ucapan "tangan Allah terbelenggu" dengan maksud, Allah itu kikir karena tidak menolong mereka.

Pertanyaan dalam ayat ini, menyatakan bahwa "tangan" orang Yahudi itulah yang terbelenggu dan mereka mendapat laknat disebabkan apa yang telah mereka katakan adalah suatu pernyataan terhadap kekikiran mereka, yakni merekalah yang kikir, terbelenggu tangannya, tidak mau memberi bantuan. Ternyata memang mereka adalah umat yang terkikir, mereka baru mau memberikan bantuan jika mereka melihat ada harapan akan mendapat keuntungan yang besar. Dan mereka pada hari kemudian pasti menerima kutukan Allah sebagai balasan atas perbuatan mereka. ${ }^{4}$ Selain itu, ada yang memahami arti "tangan mereka yang dibelenggu", sebagai perintah kepada kaum Muslimin untuk mendo'akan agar tangan mereka terbelenggu, dan bukan sebagai informasi dari Allah bahwa sesungguhnya orang-orang Yahudilah yang sangat kikir. Jika ia dipahami sebagai do'a, maka kata yang harus disisipkan adalah "berdo'alah" bukan "sesungguhnya".

${ }^{4}$ Ibid., h. 429-431 
Dengan demikian, ayat tersebut bagaikan meyatakan: Berdo'alah semoga tangan mereka dibelenggu Allah dan dilaknat atas ucapan mereka itu. ${ }^{5}$

Ayat ini juga menegaskan bahwa Allah Maha Pemurah dan Dia memberi sebagaimana yang Dia kehendaki. Perkataan "tangan" dalam bahasa Arab mempunyai beberapa arti, yaitu: 1). Salah satu dari anggota tubuh manusia, 2). Kekuatan, 3). Kepunyaan (milik), dan 4). Nikmat karunia. Pada pengertian yang keempat inilah, yang dimaksud dengan perkataan "tangan" yang disandarkan kepada Allah. Demikianlah para ulama khalaf mengartikan "tangan" pada ayat ini. Dengan demikian, hendaklah diartikan perkataan "kedua tangan Allah terbuka" dengan makna bahwa nikmat karunia Allah terbentang luas, nikmat karunia ini diberikan kepada siapa-siapa yang dikehendaki-Nya.

Ayat ini pun mengutarakan kepada Muhammad, bahwa apa yang diturunkan kepadanya benar-benar akan menambah kedurhakaan dan kekafiran bagi kebanyakan di antara kaum Yahudi dan menerangkan bahwa ayat yang diturunkan itu mengandung pengetahuan yang tidak diketahui oleh Yahudi yang semasa dengan Nabi Muhammad SAW. Karena jika tidak demikian halnya, tentulah Muhammad tidak mengetahui semua itu, sebab dia adalah ummi, tidak pandai tulis baca. Tetapi karena kedengkian dan kefanatikan, orang-orang Yahudi itu semakin jauh dari beriman kepada Nabi Muhammad, meskipun kenabian Muhammad telah ditulis di dalam kitab suci.

Ayat ini juga menerangkan, bahwa Allah akan menimbulkan permusuhan di antara sesama Ahli Kitab. Permusuhan itu tidak akan berakhir sampai hari kiamat. Watak kaum Yahudi memang suka menyalahkan api peperangan, fitnah dan keonaran. Watak seperti itu telah tercatat dalam sejarah dan membuktikan bahwa mereka selalu berusaha memperdayakan Nabi Muhammad dan orang-orang beriman, baik secara langsung maupun dengan cara membujuk orang musyrik atau orang Nasrani untuk memerangi Nabi Muhammad dan orang-orang yang beriman.

Watak seperti itu membawa mereka senang berbuat dan melihat kerusakan di bumi. Tetapi setiap mereka menyalahkan api peperangan, fitnah dan keonaran, serta memcoba membuat kerusakan, Allah tetap memadamkannya, karena Allah tidak menyukai orang-orang yang berbuat kerusakan. Oleh karenya, usaha-usaha mereka untuk membuat kerusakan dan bencana di atas bumi ini selalu mengalami kegagalan. ${ }^{6}$

Selanjutnya ayat 65 , menerangkan bahwa, andaikata ${ }^{7}$ Ahli Kitab itu beriman kepada Allah dan beriman kepada Nabi Muhammad SAW selaku nabi akhir zaman, dan mereka bertakwa dengan menjauhi pekerjaan-pekerjaan dosa, niscaya Allah mengampuni segala dosa dan kejahatan yang telah mereka perbuat. Allah akan memasukkan mereka ke dalam surga yang penuh dengan segala macam nikmat. Pengampunan Allah dan surga yang dijanjikan itu tergantung kepada iman, takwa dan taat. Iman tanpa takwa adalah suatu kemunafikan yang hanya dipergunakan untuk mencari keuntungan duniawi belaka. Menurut ayat ini Allah Maha Pengampun dan mengampuni dosa-dosa orang yang beriman dan bertakwa. ${ }^{8}$

Ayat 66 menerangkan bahwa, apabila Ahli Kitab itu benar-benar menjalankan hukum Taurat dan Injil seperti mengesakan Allah dan berpegang kepada berita gembira yang terdapat dalam Taurat dan Injil tentang kenabian Muhammad, tentulah Allah akan melapangkan kehidupan mereka. Jadi, jika pada ayat yang lalu Allah menjanjikan kebahagiaan akhirat kepada Ahli Kitab, apabila mereka beriman dan bertakwa, akan mendapat kebahagiaan duniawi dan kelapangan rezeki serta limpahan rahmat-Nya dari langit, dengan menumbuhkan berbagai tanaman. Meskipun demikian, mereka tetap durhaka dan menentang rasul-rasul Allah.

${ }^{5}$ lbid., h. 147

${ }^{6}$ Depag RI, Op.Cit., h. 431-432

${ }^{7}$ Kata law, yang berarti andaikata, jika, seandainya dalam ayat ini digunakan untuk suatu perandaian yang mustahil akan terjadi. Dengan demikian, ayat ini mengisyaratkan bahwa banyak orang Yahudi yang akan mempertahankan keyakinan mereka dan menolak ajaran Islam. Lih. Muhammad Quraish Shihab, Op.Cit., h. 148

${ }^{8}$ Depag RI, Op.Cit., h. 432-433 
Ayat ini menerangkan, bahwa di antara orang-orang Yahudi ada golongan yang bimbang dalam beragama, tidak berpegang secara fanatik kepada pendapat-pendapat para pendetanya dan tidak pula memandang ringan. Memang mayoritas orang Yahudi itu sangat fanatik kepada pendapat-pendapat para pendetanya. Golongan inilah yang buruk tingkah lakunya. Hal serupa itu terjadi dalam kalangan kaum Nasrani.

Menurut kebiasaan, meskipun golongan pertengahan dari masing-masing agama itu tidak banyak pengikutnya, namun dari kalangan mereka, timbul orang-orang yang suka memperbaiki keadaan dan mengikuti perkembangan serta menerima kebenaran. Orang-orang seperti ini terdapat pada setiap umat dan tiap-tiap masa. Umpamanya, Abdullah bin Salam dan kawan-kawannya dari kalangan Yahudi menjadi pengikut Nabi Muhammad yang setia. Demikian pula Najasyi dan kawan-kawan dari kalangan Nasrani menjadi pengikut Nabi Muhammad yang setia pula. Hal tersebut menunjukkan bahwa fungsi pemeluk agama adalah mencari kebenaran. Maka jika pemeluk suatu agama berpegang kepada petunjuk-petunjuk agama secara benar, tentulah dia tidak akan menjadi fanatik, kaku dan menerima agama yang dibenarkan di dalam kitab-kitabnya. Dalam mencari kebenaran itu, modal utama adalah keikhlasan yang disertai ilmu pengetahuan. Mencari kebenaran dengan modal ini terdapat di dalam agama Islam. Pemeluk Islam sendiri yang tidak mengamalkan petunjuk-petunjuk Islam, tentulah kebenaran yang ada pada Islam itu tidak dapat diperolehnya. Sehubungan dengan ayat ini, terdapat hadits Nabi yang diriwayatkan Ziad bin Labid, yaitu:

Ziad bin Labid, ia berkata, Nabi Muhammad SAW membicarakan sesuatu lalu beliau berkata, "Hal demikian itu adalah pada waktu ilmu pengetahuan telah lenyap". Ziad berkata, "Kami (para sahabat) berkata. "Wahai Rasulullah, bagaimanakah ilmu pengetahuan bisa lenyap, sedangkan kami membaca Al-Qur'an dan kami membacakannya pula kepada anak-anak kami, dan anak-anak kami itu membacakannya pula kepada anak-anak mereka sampai hari kiamat”. Rasulullah SAW menjawab, "Celakalah engkau hai anak Ibnu Labid, jika aku mengetahui engkau adalah orang-orang yang paling banyak ilmunya di antara penduduk Madinah, tidakkah orangorang Yahudi dan Nasrani itu membaca Taurat dan Injil, sedangkan mereka tidak mendapat manfaatnya sedikitpun”. (H.R. Ahmad) ${ }^{9}$

Selain itu, ayat ini juga adalah satu dari sekian banyak ayat yang menginformasikan adanya kaitan antara keimanan dan ketakawaan dengan kesejahteraan duniawi. Sebaliknya pun demikian, seperti yang ditegaskan dalam firman-Nya:

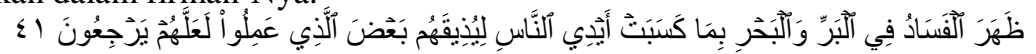

"Telah nampak kerusakan di darat dan di laut disebabkan karena perbuatan tangan manusi, supay Allah merasakan kepada mereka sebahagian dari (akibat) perbuatan mereka, agar mereka kembali (ke jalan yang benar)" (Q.S. ar-Rum 30 : 41).

Keimanan menghasilkan ketenangan dan keharmonisan, dan ketakwaan yang merupakan buah keimanan adalah upaya manusia menghindari sanksi-sanksi Allah akibat pelanggaran terhadap hukum-hukum alam yang ditetapkan serta hukum-hukum agama yang digariskan-Nya. Upaya menghindari sanksi-sanksi itu menuntut aktivitas positif dan amal saleh, dan ini pada gilirannya mengantar kepada kesejahteraan lahir dan batin. ${ }^{10}$

Kemudian ayat 67, yang memerintahkan kepada Nabi Muhammad supaya menyampaikan apa yang telah diturunkan kepadanya tanpa menghiraukan besarnya tantangan di kalangan Ahli Kitab, orang musyrik dan orang-orang fasik. Ayat ini menganjurkan kepada Nabi Muhammad agar tidak perlu takut menghadapi gangguan dari mereka dalam membentangkan rahasia dan keburukan tingkah laku mereka itu, karena Allah menjamin akan memelihara Nabi Muhammad dari gangguan, baik masa sebelum hijrah oleh kafir Quraisy maupun sesudah hijrah oleh orang Yahudi.

\footnotetext{
${ }^{9}$ Ibid., h. 433-434

${ }^{10}$ Muhammad Quraish Shihab, Op.Cit., h. 149
} 
Apa yang telah diturunkan oleh Allah kepada Muhammad adalah amanat yang wajib disampaikan seluruhnya kepada manusia. Menyampaikan sebagian saja dari amanat-Nya dianggap sama dengan tidak menyampaikan sama sekali. Demikianlah kerasnya peringatan Allah kepada Muhammad. Hal tersebut menunjukkan bahwa tugas menyampaikan amanat adalah kewajiban Rasul. Tugas penyampaian tersebut tidak boleh ditunda meskipun penudaan itu dilakukan untuk menunggu kesanggupan manusia untuk menerimanya, karena masa penundaan itu dapat dianggap sebagai suatu tindakan penyembunyian terhadap amanat Allah.

Ancaman terhadap penyembunyian sebagian amanat Allah sama kerasnya dengan ancaman terhadap sikap seseorang yang beriman kepada sebagian rasul saja dan beriman kepada sebagian ayat al-Qur'an saja. Meskipun seorang rasul bersifat maksum, yakni terpelihara dari sifat tidak menyampaikan, namun ayat ini menegaskan bahwa tugas menyampaikan amanat adalah kewajiban yang tidak dapat ditawar-tawar atau ditunda-tunda, meskipun menyangkut pribadi Rasul sendiri, seperti halnya yang kemudian terjadi antara Zainab binti Jahsy dengan Nabi Muhammad sebagai mana diuraikan dalam al-Qur'an :

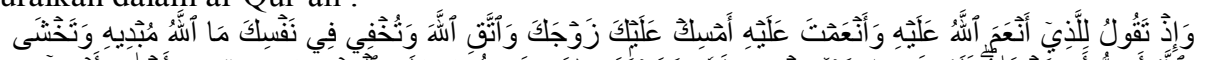

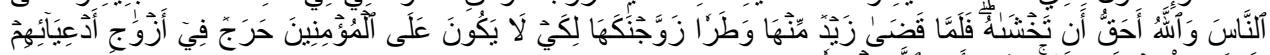

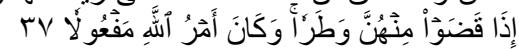

"Dan (ingatlah), ketika kamu berkata kepada orang yang Allah telah melimpahkan nikmat kepadanya dan kamu (juga) telah memberi nikmat kepadanya: "Tahanlah terus isterimu dan bertakwalah kepada Allah", sedang kamu Menyembunyikan di dalam hatimu apa yang Allah akan menyatakannya, dan kamu takut kepada manusia, sedang Allah-lah yang lebih berhak untuk kamu takuti. Maka tatkala Zaid telah mengakhiri keperluan terhadap Istrinya (menceraikannya), Kami kawinkan kamu dengan dia supaya tidak ada keberatan bagi orang mukmin untuk (mengawini) isteri-isteri anak-anak angkat mereka, apabila anak-anak angkat itu telah menyelesaikan keperluannya daripada isterinya. dan adalah ketetapan Allah itu pasti terjadi” (Q.S. al-Ahzab 33 : 37).

Berdasarkan terjemahan diatas dalam hubungan ini Aisyah dan Anas berkata, "Kalaulah kiranya Nabi Muhammad akan menyembunyikan sesuatu dalam Al-Qur'an, tentu ayat inilah yang disembunyikannya". Dari keterangan Aisyah dan Anas ini jelaslah peristiwa yang kemudian terjadi antara Zainab bin Jahsy dengan Zaid ialah perceraian yang berkelanjutan dengan berlakunya kehendak Allah yaitu menikahkan Zainab dengan Nabi Muhammad. Hal tersebut tidak dikemukakan oleh Nabi Muhammad kepada Zaid ketika ia mengadukan peristiwanya kepada Nabi Muhammad pada hal beliau sudah mengetahuinya dengan perantaraan wahyu. Nabi Muhammad SAW menyembunyikan hal-hal yang diketahuinya sesuai dengan kesopanan di samping menghindarkan tuduhan-tuduhan yang dilancarkan oleh golongan orang-orang munafik. Meskipun demikian, Nabi Muhammad masih juga menerima kritik Allah seperti diketahui pada ayat dalam surat al-Ahzab tersebut.

Tegasnya, ayat 67 ini mengancam orang-orang yang menyembunyikan amanat Allah sebagaimana tersebut dalam firman-Nya:

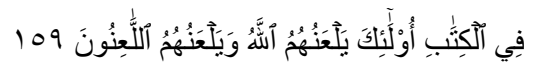

"Sesungguhnya orang-orang yang menyembunyikan apa yang telah Kami turunkan berupa keterangan-keterangan (yang jelas) dan petunjuk, setelah Kami menerangkannya kepada manusia dalam Al-Kitab, mereka itu dila'nati Allah dan dila'nati (pula) oleh semua (mahluk) yang dapat mela'nati” (Q.S. al-Baqarah 2 : 159)

Sejalan dengan ancaman Al-Qur'an ini, Nabi Muhammad bersabda mengingatkan orangorang yang menyembunyikan ilmu pengetahuan: "Barangsiapa ditanya tentang sesuatu ilmu pengetahuan lalu disembunyikannya, maka ia akan dikekang pada hari kiamat dengan kekangan dari api neraka” (H.R. Abu Daud, at-Tirmidzi dari Abu Hurairah). 
Pada akhir ayat ini ditegaskan, bahwa Allah tidak akan memberi petunjuk kepada orangorang kafir yang mengganggu Nabi Muhammad dan pekerjaan mereka itu pastilah sia-sia karena Allah tetap melindungi Nabi-Nya dan tetap akan meninggikan kalimat-Nya. ${ }^{11}$

Selanjutnya, pada ayat 68 Allah memerintahkan kepada Muhammad supaya mengatakan kepada Ahli Kitab bahwa mereka itu tidak dapat dipandang sebagai orang yang beragama selagi mereka tidak menegakkan ajaran-ajaran Taurat, Injil dan ajaran-ajaran yang telah diturunkan kepada Nabi Muhammad yaitu Al-Qur'an, karena kalau mereka menegakkan ajaran Taurat dan Injil, tentulah tidak ada golongan yang mereka musuhi dan mereka laknati. Jika ada orang lain yang mengganggu, tentulah mereka memberikan maaf bahkan mereka akan memberikan pipi kirinya ketika dipukul orang pada pipi kanannya.

Mereka tidak akan berlomba dalam mempersiapkan senjata-senjata yang menghancurkan dunia demi keselamatan manusia di dunia. Untuk perdamaian itu tentulah mereka akan mengeluarkan kekayaan mereka. Tetapi kenyataannya bahwa tingkah laku mereka adalah sebaliknya tidak menunjukkan bahwa mereka itu orang yang berpegang kepada agama. Malah kebanyakan mereka bertambah kedurhakaan dan kekafiran terhadap sesuatu yang diturunkan Allah kepada Nabi Muhammad, yaitu Al-Qur'an selaku kitab penyempurna agama Allah. Hal itu menggambarkan bahwa mereka tidak beriman sungguh-sungguh kepada Allah dan tidak beriman sungguh-sungguh kepada rasul-rasul. Tegasnya mereka tidak melakukan perbuatan-perbuatan yang baik yang dituntut oleh Kitab-kitab mereka. Jadi kebanyakan mereka itu hanya berpegang kepada adat istiadat yang buruk dan kefanatikan, karenanya mereka menolak Al-Qur'an, secara sadar disebabkan mereka jauh dari ajaran agama mereka yang sebenarnya.

Agama sebelum Muhammad merupakan dasar dari agama yang dibawa Nabi Muhammad, karena Islam merupakan penyempurna agama-agama sebelumnya. Oleh karena mereka melihat Al-Qur'an dengan kacamata permusuhan dan kefanatikan, bertambah-tambahlah kefanatikan dan kedurhakaan mereka. Memang ada segolongan kecil dari mereka yang memelihara ajaran Tauhid, yang cinta kepada kebenaran; mereka inilah orang yang memandang al-Qur'an dengan kesadaran, karena mereka meyakini bahwa Al-Qur'an itu sebenarnya dari Tuhan mereka, dan bahwa Nabi yang Al-Qur'an diturunkan kepadanya adalah Nabi yang terakhir yang tertulis dalam kitab-kitab mereka, sehingga mereka ini beriman kepada Muhammad seperti ulama-ulama Yahudi dan Najasyi dari kalangan Nasrani. Dan pada akhir ayat ini melarang Nabi Muhammad berduka cita terhadap orang-orang kafir yang tidak menyambut seruannya agar mereka beriman kepada AlQur'an. ${ }^{12}$

Ayat ini sekali lagi menekankan bahwa wahyu-wahyu yang diterima oleh Nabi Muhammad SAW menambah kedurhakaan mereka. Betapa tidak bertambah dengki dan panas hati mereka, sedangkan mereka merasa diri mereka yang paling tahu tentang kitab suci, menilai Nabi Muhammad SAW dan orang-orang Arab sebagai ummiyin, yang boleh ditipu. ${ }^{13}$ Akan tetapi, wahyu-wahyu yang diterima Nabi SAW dari saat ke saat membuka keburukan mereka satu demi satu dan membongkar rahasia yang mereka ingin tutup rapat. Maka, wajar jika setiap wahyu yang demikian itu kandungannya melahirkan lebih banyak lagi kedengkian serta menambah pelampauan batas dan kedurhakaan mereka. ${ }^{14}$

${ }^{11}$ Depag RI, Op.Cit., h. 437-439

12 Ibid., h. 439-440

13 "Di antara ahli kitab ada orang yang jika kamu mempercayakan kepadanya harta yang banyak, dikembalikannya kepadamu; dan di antara mereka ada orang yang jika kamu mempercayakan kepadanya satu dinar, tidak dikembalikannya kepadamu kecuali jika kamu selalu menagihnya. yang demikian itu lantaran mereka mengatakan: "tidak ada dosa bagi Kami terhadap orang-orang ummi. Mereka berkata Dusta terhadap Allah, Padahal mereka mengetahui" (Q.S. al-Imran $3:$ 75)

\footnotetext{
${ }^{14}$ Muhammad Quraish Shihab, Op.Cit., h. 154
} 
Pada ayat 69 dari segi pengertiannya tidak ada perbedaannya dari ayat 62 Surah Al-Baqarah. Ia diulang kembali, dengan susunan yang berbeda. Sejalan dengan ayat sebelumnya yaitu ayat 62 , yang memerintahkan kepada Muhammad supaya mengatakan kepada Ahli Kitab, bahwa mereka belum dipandang beragama selama mereka belum beriman kepada Allah dengan sesungguhnya dan mengamalkan tuntunan Taurat dan Injil serta ajaran Al-Qur'an, maka pada ayat ini Allah menerangkan bahwa hal itu berlaku pada pengikut-pengikut semua rasul sebelum Muhammad, yaitu Yahudi, Nasrani dan Sabi'in (bukan Yahudi dan Nasrani). Jika mereka menjalankan petunjuk-petunjuk agamanya sebelum terjadi perubahan oleh tangan mereka, tentulah mereka tidak khawatir pada hari kemudian, dan mereka yang menemui Nabi Muhammad tetapi menentangnya atau pura-pura beriman, manakala mereka itu bertobat dan beramal saleh, tentulah mereka tidak khawatir pada hari kemudian, karena seseorang itu tidak ada kelebihannya kecuali jika ia beriman kepada Allah dan kepada hari kemudian serta beramal saleh.

Manusia mempunyai dua macam kekuatan: pertama, kekuatan di bidang teori, dan kedua, kekuatan di bidang praktek dan amaliah. Kekuatan di bidang teori barulah mencapai kesempurnaannya jika manusia itu mempunyai ilmu pengetahuan. Ilmu pengetahuan manusia baru mencapai kesempurnaan, jika sampai pada pengetahuan tentang sesuatu yang paling mulia, yaitu Allah Tuhan Yang Maha Esa dan Mahakuasa membangkitkan dan menghimpun manusia di padang Mahsyar. Dengan demikian pengetahuan yang paling mulia adalah keimanan kepada Allah dan hari kemudian. Amal kebaikan yang paling mulia adalah berbakti kepada Allah dan berusaha menyampaikan hal-hal yang bermanfaat kepada manusia. Jadi, orang-orang yang menghadap Allah dengan keimanan dan amalan-amalan seperti ini tentulah dia tidak akan khawatir sedikit pun terhadap huru-hara dan bencana hari kiamat, dan mereka tidak bersedih hati terhadap nikmat dunia yang tidak pernah mereka rasakan ketika hidup di dunia. ${ }^{15}$

Kemudian, ayat 70 menerangkan bahwa Allah mengambil janji dari Bani Israil, yaitu berupa ikrar mereka untuk beriman kepada Allah dan mengamalkan isi Taurat selaku syariah yang diturunkan Allah kepada mereka. Untuk memberikan penjelasan isi kitab tersebut, Allah mengutus rasul-rasul-Nya ${ }^{16}$ kepada mereka. Tetapi setiap kali datang kepada mereka seorang rasul yang membawa petunjuk yang tidak sesuai dengan keinginan mereka, mereka perlakukan rasul itu dengan perlakuan yang sangat keji.

Segolongan mereka mendustakan rasul dan sebagian mereka menganiaya dan membunuh rasul. Hal itu menunjukkan betapa jahatnya tingkah laku mereka sehingga petunjuk yang dibawa oleh rasul tidak sedikit pun berkesan di hati mereka, malahan kekufuran dan kezaliman mereka yang semakin bertambah-tambah. ${ }^{17}$

Selanjutnya, ayat 71 menerangkan bahwa orang-orang Yahudi itu tidak menduga bahwa Allah akan memberikan cobaan yang maha berat disebabkan perbuatan mereka yang sangat keji dan kekejaman yang melampaui batas, karena mereka menganggap bahwa mereka adalah anak Allah dan kekasih-Nya, karenanya mereka menganggap bebas dari azab Allah. Mereka seolah-olah buta akan kenyataan-kenyataan yang menunjukkan siksaan-siksaan Allah terhadap umat yang membuat kerusakan dan kezaliman. Mereka seolah-olah tuli akan ajaran-ajaran dan petunjukpetunjuk yang penuh mengandung ancaman-ancaman Allah; yaitu siksa terhadap orang-orang yang membatalkan janji-janji yang telah diikrarkan karena mengikuti selera untuk berbuat kezaliman.

Menurut sejarah, ketika bangsa Babilonia berada di bawah kekuasaan Nebukadnezar sekitar tahun 586 SM menaklukkan bangsa Yahudi, mereka menghancurkan Kuil Sulaiman di Baitulmakdis, merampas harta benda dan memperkosa wanita. Setelah orang-orang Yahudi kembali ke ajaran Taurat dan bertobat kepada Allah, barulah Allah memberikan pertolongan kepada mereka untuk melepaskan diri dari kekejaman bangsa Babilonia. Tetapi setelah

${ }^{15}$ Depag RI, Op.Cit., h. 440

${ }^{16}$ Seperti Yusya' Ibn Nun, Hazqiyal, Daud, Musa dan Isa AS. Lih. Muhammad Quraish Shihab, Op.Cit., h. 158

${ }^{17}$ Depag RI, Op.Cit., h. 440-441 
penglihatan mereka buta terhadap peringatan, dan telingan mereka tuli terhadap petunjuk-petunjuk Allah, mereka kembali berbuat kezaliman membunuh rasul-rasul, maka datanglah lagi cobaan Allah, yaitu mereka secara silih berganti dikuasai oleh kerajaan Romawi. Memang yang berbuat kejahatan tidaklah semua orang Yahudi dengan adanya kenyataan segolongan kecil dari mereka yang berbuat baik, tetapi sudah menjadi sunnatullah bahwa cobaan Tuhan itu menimpa secara merata kepada seluruh umat akibat perbuatan golongan yang zalim. Allah sudah memperingatkan dalam firman-Nya:

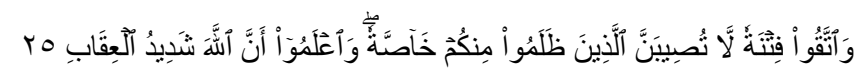

"Dan peliharalah dirimu dari pada siksaan yang tidak khusus menimpa orang-orang yang zalim saja di antara kamu. dan ketahuilah bahwa Allah Amat keras siksaan-Nya” (Q.S. Al-Anfal $8: 25$ )

Selanjutnya akhir ayat ini menerangkan bahwa Allah Maha Melihat tindakan atau kelakuan orang Yahudi terhadap Nabi Muhammad, baik tipu daya maupun berupa pengerahan segenap kabilah-kabilah untuk bersatu menyerang Nabi Muhammad, karena dorongan nafsu jahat mereka yang telah membuat mereka buta, ketika dikemukakan bukti-bukti kebenaran oleh Nabi Muhammad selaku Nabi penutup semua nabi. ${ }^{18}$

Di samping itu, penutup ayat ini juga mengisyaratkan bahwa Allah tidak seperti makhluk yang seringkali tertipu oleh nama besar dan kehormatan semu yang disandang seseorang atau satu bangsa. Allah tidak demikian, Dia Maha Mengetahui seluk beluk dan rincian apapun yang dilakukan oleh makhluk-Nya. Kata bashir (Maha Melihat) terambil dari akar kata bashara, sedangkan kata yang tersusun dari huruf-huruf $b a$, shad dan $r a$ ', pada dasarnya mengandung makna ilmu atau pengetahuan tentang sesuatu. Karena itu, sebagaian ulama menyatakan sifat Maha Mendengar dan Melihat Allah adalah dua sifat yang identik dengan ilmu. Allah Maha Melihat itu adalah Dia yang menyaksikan segala sesuatu lahir dan batinnya, besar dan kecilnya, sehingga apa yang tersembunyi di bawah dasar lautan pun dijangkau-Nya. ${ }^{19}$

\section{Analisis Pendidikan}

Berdasarkan analisa, penulis mencoba membagi surat al-Maidah ayat 64-71 tersebut menjadi dua bagian, pertama, pada ayat antara 64-66, umumnya bertutur tentang kisah orang-orang Yahudi yang memperoleh kutukan atau laknat dari Allah akibat ucapan buruk yang lahir dari kedengkian dan kebencian terhadap Nabi Muhammad SAW. Ayat-ayat tersebut sesungghunya mengisahkan bahwa tidaklah benar tuduhan orang Yahudi yang mengatakan bahwa tangan Allah terbelenggu, justru sebaliknya tangan Allah ini terbuka, karena telah melimpahkan rahmat-Nya kepada seluruh hamba-Nya, baik yang kafir maupun yang mukmin.

Pemaparan tersebut dalam konteks pendidikan memberikan gambaran bahwa, kisah sebagaimana tersebut di atas bisa dijadikan contoh dari metode pendidikan. Allah menggunakan cerita atau pun kisah; cerita sejarah faktual yang menampilkan suatu contoh kehhidupan manusia yang dimaksudkan agar manusia bisa berpikir dan mengambil pelajaran dari kisah tersebut.

Menurut bahasa Arab, kata kisah atau cerita adalah qishah bentuk jamaknya adalah qhashas, yang berarti kisah atau cerita, ${ }^{20}$ sedangkan dalam bahasa Inggris adalah story, tale, dan narrative yang berarti pula cerita. ${ }^{21}$ Dengan demikian metode kisah mengandung arti suatu cara dalam menyampaikan materi pelajaran dengan menceritakan secara kronologis tentang bagaimana terjadinya sesuatu hal, yang menuturkan perbuatan, pengalaman atau penderitaan orang lain baik yang sebenarnya terjadi ataupun hanya rekaan saja. Metode kisah yang disampaikan

${ }^{18}$ Ibid., h. 441-442

${ }^{19}$ Muhammad Quraish Shihab, Op.Cit., h. 160

${ }^{20}$ Mahmud Yunus, Kamus Arab Indonesia, (Jakarta: Yayasan Penyelenggara Penterjemah dan Pentafsir Al-Qur'an, 1973), h. 343

21 John M. Echols dan Hasan Shadily, Kamus Inggris Indonesia, (Jakarta: Gramedia, 1983), h. 135 
merupakan salah satu metode pendidikan yang masyur dan terbaik, sebab kisah itu mampu menyentuh jiwa jika didasarkan oleh ketulusan hati yang mendalam. ${ }^{22}$

Di jelaskan dalam pendidikan Islam bagi anak pelaksanaan metode kisah tidak akan terlepas dari pertimbangan sebagai berikut : 1). Tingkat Perkembangan Anak. Pelajaran yang disampaikan kepada anak hendaknya menyesuaikan kemampuan anak, sebab hal ini menjadi bahan pertimbangan apakah anak dapat menangkap apa yang akan diceritakan atau tidak. Bila anak dapat menangkap apa yang disampaikan, salah satunya berarti materi yang disampaikan sesuai dengan tingkat perkembangan anak. Untuk menerapkan metode ini, diharapkan pendidik mengetahui tingkat perkembangan anak, yang dalam hal ini dapat diketahui melalui dari tingkat usia atau kemampuan anak. Dalam psikologi pendidikan dijelaskan tentang tingkat perkembangan dan beberapa bobot materi yang akan disampaikan, khususnya yang berkaitan dengan materi pendidikan agama. $^{23}$

Kemudian, 2). Tujuan yang hendak dicapai. Metode kisah atau cerita sangat efektif dalam pencapaian tujuan pendidikan Islam sebab dalam cerita memberikan kisah pelajaran kepada anak didik untuk senantiasa berfikir mengekspresikan sikap, serta terampil berperilaku sesuai dengan kandungan yang diharapkan oleh isi cerita atau kisah. Tujuan metode kisah pada aspek kognitif, afektif maupun psikomotorik, yang perwujudannya sesuai dengan pesan-pesan yang disampaikan oleh Rasulullah yang di antaranya berkaitan dengan masalah akidah, ibadah dan masalah muamalah. $^{24}$

Menurut Moeslichatoen manfaat metode kisah di antaranya sebagai berikut : a). Mengkomunikasikan nilai-nilai budaya. b). Mengkomunikasikan nilai-nilai sosial. c). Mengkomunikasikan nilai-nilai keagamaan. d). Menanamkan etos kerja, etos waktu, etos alam. e). Membantu mengembangkan fantasi anak. f). Membantu mengembangkan dimensi kognitif anak. g). Membantu mengembangkan dimensi bahasa anak. ${ }^{25}$

Selanjutnya 3). Materi yang disampaikan. Materi atau bahan pelajaran yang harus disampaikan oleh guru kepada anak didik untuk mencapai suatu tujuan pendidikan yang diinginkan, yaitu kognitif, afektif dan psikomotorik harus sesuai dengan ajaran Islam. Guru harus pandai-pandai menyampaikan materi dengan baik sesuai dengan taraf perkembangan anak, meskipun dalam hal ini tidak terlepas pula dari peran serta guru, orang tua, dan masyarakat, juga metode yang digunakan.

Di antara materi yang perlu diterapkan dengan metode kisah adalah materi yang berkaitan dengan masalah akidah, misalnya larangan menyekutukan Allah, materi yang berkaitan dengan masalah ibadah, misalnya shalat, zakat dan puasa, kemudian materi yang berkaitan dengan masalah muamalah, misalnya larangan riba dan serta materi yang berkaitan dengan peristiwaperistiwa yang ada dalam Al-Qur'an seperti kisah Nabi Nuh, Nabi Ibrahim, Nabi Musa dan lain sebagainya, yang banyak memberikan teladan dan pelajaran hidup dalam rangka pengamalan ajaran agama. Sedangkan mengenai materi pelajaran dan metode pengajaran yang sesuai merupakan faktor penting dalam keterbukaan dan kesediaan anak untuk belajar. Cukuplah bahwa penggunaan kata-kata sukar dan samar dalam mengajar anak didik membaca dan menulis atau menggunakan metode yang gersang dalam mengajar, akan memalingkan anak dari materi pelajaran, serta menimbulkan kebosanan dalam diri mereka. Lain halnya jika diajarkan kepada mereka kata-kata yang biasa dan tepat melalui penyampaian materi dengan metode kisah. ${ }^{26}$

${ }^{22}$ Armai Arief, Pengantar Ilmu dan Metodologi Pendidikan Islam, (Jakarta: Ciputat Pers, 2002), h. 160

${ }^{23}$ Wasty Soemanto, Psikologi Pendidikan; Landasan Kerja Pemimpin Pendidikan, (Jakarta: Rineka Cipta, 1998), h. 177-180

${ }^{24}$ Ali Syawakh Ishaq, Metodologi Pendidikan Al-Qur'an dan Sunnah, Terj. Asmu'i Saliha Zakhsyari, (Jakarta: Pustaka Al-Kautsar, 1995), h. 89

25 Moeslichatoen, Metode Pengajaran di Taman Kanak-kanak, (Jakarta: Rineka Cipta, 1999), h. 26-27.

${ }^{26}$ Zakiah Daradjat, Kepribadian Guru, (Jakarta: Bulan Bintang, 1982), h. 25. 
Kemudian yang 4). Keterampilan guru. Sebagaimana tujuan di atas terutama dalam rangka memberikan pengalaman belajar dan untuk mencapai tujuan pengajaran, misalnya tentang pemberian informasi atau menanamkan nilai-nilai moral, nilai-nilai sosial dan nilai-nilai keagamaan, guru harus pandai-pandai mengaitkan materi yang telah dipilih. Tema tersebut harus ada kedekatannya dengan kehidupan anak dalam keluarga, sekolah, maupun masyarakat. Tema juga harus menarik dan memikat perhatian anak. Sedangkan 5). Sarana yang dipakai. Dalam bercerita, maka sarana yang dipakai seharusnya disesuaikan dengan bentuk atau kisah cerita yang dituturkan guru. Pada dasarnya ada tiga sarana yang bisa digunakan guru dalam hal ini yaitu bercerita dengan menggunakan ilustrasi gambar, bercerita dengan membaca buku atau majalah dan bercerita dengan menggunakan papan flannel. ${ }^{27}$

Selanjutnya pada bagian yang kedua, pada ayat 67-71 secara garis besar bercerita tentang kewajiban Rasulullah SAW dalam menyampaikan agama Islam, terutama pada ayat 67 yang menjelaskan secara gamblang tentang kewajiban tersebut. Dalam konteks pendidikan, Kata baligh pada ayat ini, menurut bahasa Arab artinya sampai, mengenai sasaran, atau mencapai tujuan. Kata ini dalam bahasa Arab itu merupakan pernyataan yang sangat jelas apalagi bentuknya fi' il amr. Dalam tafsir al-Jalalin lafadz baligh terselip kandungan makna yakni seluruhnya. ${ }^{28}$ Berarti Nabi harus menyampaikan secara keseluruhan yang telah diterima dari Allah SWT. Tidak boleh ada yang disembunyikan sedikitpun dari Nabi. ${ }^{29}$ Dalam Tafsir Ibnu Katsir juga dijelaskan bahwa makna baligh dalam surat Al-Maidah merupakan fiil amr yang terkandung makna untuk menyampaikan seluruh yang diterima dari Allah SWT. ${ }^{30}$

Bila dikaitkan dengan qawl (ucapan), kata baligh berarti fasih, jelas maknanya, terang, tepat mengungkapkan apa yang dikehendaki. Karena itu prinsip qaulan balighan dapat diterjemahkan sebagai prinsip komunikasi yang effektif. Komunikasi yang efektif dan efisien dapat diperoleh bila memperhatikan pertama, bila dalam pendidikan menyesuaikan pembicaranya dengan sifat khalayak. Istilah al-Quran fii anfusihiim, artinya penyampaian dengan "bahasa" masyarakat setempat. Hal yang kedua agar komunikasi dalam proses pembelajaran dapat diterima peserta didik manakala komunikator menyentuh otak atau akal juga hatinya sekaligus. ${ }^{31}$

Kemampuan bicara berarti kemampuan berkomunikasi. Berkomunikasi adalah sesuatu yang dihajatkan di hampir setiap kegiatan manusia. Dalam sebuah penelitian telah dibuktikan, hampir $75 \%$ sejak bangun dari tidur manusia berada dalam kegiatan komunikasi. Dengan komunikasi kita dapat membentuk saling pengertian dan menumbuhkan persahabatan, memelihara kasih sayang, menyebarkan pengetahuan, dan melestarikan peradaban. Tetapi, dengan komunikasi kita juga dapat menumbuhsuburkan perpecahan, menghidupkan permusuhan, menanamkan kebencian, merintangi kemajuan, dan menghambat pemikiran.

Kenyataan ini sekaligus memberi gambaran betapa kegiatan komunikasi bukanlah sesuatu yang mudah dilakukan oleh setiap manusia. Anggapan ini barangkali didasarkan atas dasar asumsi bahwa komunikasi merupakan suatu yang lumrah dan alamiah yang tidak perlu dipermasalahkan.

27 Admin, Pelaksanaan Metode Kisah dalam Proses Pendidikan Islam, http://www.perkuliahan.com/makalah-metode-kisah-dalam-pendidikan-islam/, diakses tanggal 18 Januari 2014

${ }^{28}$ Al-Imamul Jalalain, Tafsir Al-Qur'an al-Adzim, ( Indonesia: Maktabah Dar Ihya al-Kutub al-Arabiyah, tt), h. 104. Kitab tafsir ini terkenal dengan nama tafsir "Jalalain", artinya dua Jalal. Yang dimaksud dengan dua Jalal adalah nama tokoh ilmuwan Islam dalam bidang tafsir yaitu Jalaluddin Muhammad Ibn Ahmad Mahalli dan Jalaluddin Abdurahaman ibn Abi Bakr Asy-Syuyuti. Di pesantren kitab tafsir ini menjadi salah satu kitab tafsir wajib yang harus dipelajari bagi setiap santri ( menjadi kontens kurikulumnya pesantren)

\footnotetext{
${ }^{29}$ Ibid.

${ }^{30}$ Ibnu Katsir, Tafsir Ibnu Katstir (CD. Holly Qur,an )

${ }^{31}$ Jalaludin Rahmat, Islam Aktual, (Bandunng : Mizan, 1992), h. 78
} 
Sedemikian lumrahnya, sehingga seseorang cenderung tidak melihat kompleksitasnya atau tidak menyadari bahwa dirinya sebenarnya berkekurangan atau tidak berkompeten dalam kegiatan pribadi yang paling pokok ini. Dengan demikian, berkomunikasi secara efektif sebenarnya merupakan suatu perbuatan yang paling sukar dan kompleks yang pernah dilakukan seseorang.

Untuk itu, demi terciptanya suasana kehidupan yang harmonis antar anggota masyarakat, maka harus dikembangkan bentuk-bentuk komunikasi yang beradab, yang digambarkan oleh Jalaluddin Rahmat, yaitu sebuah bentuk komunikasi di mana sang komunikator akan menghargai apa yang mereka hargai; ia berempati dan berusaha memahami realitas dari perspektif mereka. Pengetahuannya tentang khalayak bukanlah untuk menipu, tetapi untuk memahami mereka, dan bernegosiasi dengan mereka, serta bersama-sama saling memuliakan kemanusiaannya. Adapun gambaran kebalikannya yaitu apabila sang komunikator menjadikan pihak lain sebagai obyek; ia hanya menuntut agar orang lain bisa memahami pendapatnya; sementara itu, ia sendiri tidak bisa menghormati pendapat orang lain. Dalam komunikasi bentuk kedua ini, bukan saja ia telah mendehumanisasikan mereka, tetapi juga dirinya sendiri. ${ }^{32}$

Di paparkan dalam Al-Qur'an sendiri banyak memuat istilah-istilah gaya komunikasi sebagai salah satu metode pendidikan. Istilah-istilah tersebut adalah Qaulan Sadidan (Q.S. $4: 9)$, ${ }^{33}$ Qaulan Maysuran (Q.S. 17 : 28), ${ }^{34}$ Qaulan Layinan (Q.S. 20 : 44), ${ }^{35}$ Qaulan Kariman (Q.S. 17 : 23), ${ }^{36}$ Qaulan Mau'rufan (Q.S. 4 : 5) ${ }^{37}$ dan istilah Qaulan Balighon (Q.S. 4 : 63). ${ }^{38}$

Pendidikan, seperti diketahui, bukanlah bersifat indokrinasi atau propaganda, akan tetapi, suatu proses yang bersifat komunikatif. Dalam hal ini, bisa digunakan prinsip-prinsip qaul maisur, yaitu segala bentuk perkataan yang baik, lembut, dan melegakan; menjawab dengan cara yang sangat baik, benar dan tidak mengada-ada; mengucapkan dengan cara yang wajar. Semakin bertambah umur, maka metode yang digunakan tentu saja berbeda ketika masih anak-anak. Namun, secara prinsip tetap sama, yaitu melahirkan generasi yang berkaraker. Misalnya, pada saat sudah dewasa, maka yang diterapkan adalah prinsip-prinsip qaul sadida, yang di antaranya adalah tepat sasaran dan logis, memiliki kesesuaian antara apa yang ada di dalam hati dengan yang diucapkan.

${ }^{32}$ Ibid., h. 63

33 "Dan hendaklah takut kepada Allah orang-orang yang seandainya meninggalkan dibelakang mereka anak-anak yang lemah, yang mereka khawatir terhadap (kesejahteraan) mereka. Oleh sebab itu hendaklah mereka bertakwa kepada Allah dan hendaklah mereka mengucapkan perkataan yang benar" (Q.S. an-Nisa' 4 : 9)

34 "Dan jika kamu berpaling dari mereka untuk memperoleh rahmat dari Tuhanmu yang kamu harapkan, Maka katakanlah kepada mereka ucapan yang pantas” (Q.S. al-Isra'17 : 28)

35 "Maka berbicaralah kamu berdua kepadanya dengan kata-kata yang lemah lembut, Mudah-mudahan ia ingat atau takut" (Q.S. Thaahaa $20: 44)$

36 "Dan Tuhanmu telah memerintahkan supaya kamu jangan menyembah selain Dia dan hendaklah kamu berbuat baik pada ibu bapakmu dengan sebaik-baiknya. Jika salah seorang di antara keduanya atau kedua-duanya sampai berumur lanjut dalam pemeliharaanmu, Maka sekalikali janganlah kamu mengatakan kepada keduanya perkataan "ah" dan janganlah kamu membentak mereka dan ucapkanlah kepada mereka perkataan yang mulia" (Q.S. al-Isra' $17: 23$ )

37 "Dan janganlah kamu serahkan kepada orang-orang yang belum sempurna akalnya, harta (mereka yang ada dalam kekuasaanmu) yang dijadikan Allah sebagai pokok kehidupan. Berilah mereka belanja dan pakaian (dari hasil harta itu) dan ucapkanlah kepada mereka kata-kata yang baik" (Q.S. an-Nisa' $4: 5$ )

38 “Mereka itu adalah orang-orang yang Allah mengetahui apa yang di dalam hati mereka. Karena itu berpalinglah kamu dari mereka, dan berilah mereka pelajaran, dan katakanlah kepada mereka perkataan yang berbekas pada jiwa mereka" (Q.S. an-Nisa' 4 : 63) 
Di sini proses komunikasi pendidikan Islam tidak hanya dipahami sebagai proses transfer pengetahuan yang bersifat satu arah; akan tetapi, harus ada upaya yang sungguh-sungguh dari pihak pendidik/guru, sebagai komunikator, untuk mampu memberikan keteladan yang baik, sebagai upaya bermeta-komunikasi. Juga kedua orang tuanya sebagai pendidik pertama dan utama bagi anak-anaknya. Bahkan, secara naluriah, seorang anak sangat senang dan bangga jika bisa meneladani kedua orang tuanya. Ketidaksempurnaan proses komunikasi pendidikan Islam terjadi, misalnya hanya mengajarkan pelajaran-pelajaran yang berbasis kompetensi tetapi tidak menanamkan nilai-nilai berbasis karakter atau akhlak. Bahkan, hal ini bisa dianggap sebagai bentuk kriminalitas pendidikan. Faktor kegagalan guru/orang tua dalam proses pendidikan, antara lain, disebabkan kegagalan membangun komunikasi yang beradab tersebut.

Untuk itu, dengan gaya komunikasi seperti disebutkan di atas melalui pendidikan Islam, kita dapat membentuk saling pengertian dan menumbuhkan persahabatan, memelihara kasih sayang, menyebarkan pengetahuan, dan melestarikan peradaban. Tetapi, dengan komunikasi kita juga dapat menumbuhsuburkan perpecahan, menghidupkan permusuhan, menanamkan kebencian, merintangi kemajuan, dan menghambat pemikiran.

\section{KESIMPULAN}

Berdasarkan uraian di atas, dapat ditarik kesimpulan bahwa Al-Qur'an surat al-Maidah ayat 64-71, secara umum membahas dua hal penting, yakni pertama, kisah orang-orang Yahudi yang memperoleh kutukan atau laknat dari Allah akibat ucapan buruk yang lahir dari kedengkian dan kebencian terhadap Nabi Muhammad SAW. Kedua, kewajiban Rasulullah SAW dalam menyampaikan agama Islam. Dua hal ini, jika dikaitkan dalam konteks pendidikan Islam, maka tersirat adanya pesan pendidikan Islam berupa sebuah metode pendidikan yang berupa metode kisah dalam satu sisi, dan pada sisi yang lain menggambarkan tentang petunjuk komunikasi. Metode kisah atau pun komunikasi yang efektif merupakan dua hal yang cukup penting dalam mengejawantahkan sebuah proses pendidikan Islam. Dengan demikian, secara umum Al-Qur'an, khususnya surat al-Maidah ayat 64-71 dapat dijadikan sebagai petunjuk penafsiran tafsir sosial kependidikan.

Ayat-ayat tersebut dalam konteks pendidikan memberikan gambaran bahwa, kisah sebagaimana tersebut pada surat al-Maidah ayat 64-66 bisa dijadikan contoh dari metode pendidikan. Allah menggunakan cerita atau pun kisah kutukan terhadap orang-orang Yahudi; cerita sejarah faktual yang menampilkan suatu contoh kehidupan manusia yang dimaksudkan agar manusia bisa berpikir dan mengambil pelajaran dari kisah tersebut, sehingga dapat terhindar dari kemurkaan Allah SWT, seperti yang dialami orang-orang Yahudi tersebut. Pada konteks pendidikan Islam, penuturan kisah ini dapat dijadikan sebagai metode dalam proses pendidikan Islam. Karena metode kisah merupakan salah satu metode pendidikan yang masyur dan terbaik, sebab kisah itu mampu menyentuh jiwa jika didasarkan oleh ketulusan hati yang mendalam.

Kemudian, pada surat al-Maidah ayat 67-71 menceritakan tentang kewajiban Rasulullah SAW dalam menyampaikan agama Islam, terutama pada ayat 67 yang menjelaskan secara jelas tentang kewajiban tersebut. Dalam konteks pendidikan Islam, penyampaian pesan agama Islam tersebut setidaknya memperhatikan pertama, bila dalam pendidikan menyesuaikan pembicaranya dengan sifat khalayak. Istilah Al-Quran fii anfusihiim, artinya penyampaian dengan "bahasa" masyarakat setempat. Hal yang kedua agar gaya komunikasi dalam proses pembelajaran dapat diterima peserta didik manakala komunikator menyentuh otak atau akal juga hatinya sekaligus

\section{REFERENSI}

Arief, Armai, Pengantar Ilmu dan Metodologi Pendidikan Islam, Jakarta, Ciputat Pers, 2002

Al-Qur'an dan Terjemahannya

Daradjat, Zakiah, Kepribadian Guru, Jakarta, Bulan Bintang, 1982 
Depag RI, Al-Qur'an dan Tafsirnya, Jilid 2 Juz 4,5,6 Jakarta, Depag RI, 2009

Echols, John M., dan Hasan Shadily, Kamus Inggris Indonesia, Jakarta, Gramedia, 1983

Ishaq, Ali Syawakh, Metodologi Pendidikan Al-Qur'an dan Sunnah, Terj. Asmu'i Saliha Zakhsyari, Jakarta, Pustaka Al-Kautsar, 1995

Jalalain, Al-Imamul, Tafsir Al-Qur'an al-Adzim, Indonesia, Maktabah Dar Ihya al-Kutub alArabiyah, $\mathrm{tt}$

Katsir, Ibnu, Tafsir Ibnu Katstir, CD. Holly Qur,an

Langgulung, Hasan, Tujuan Pendidikan dalam Islam, Diktat, Fakultas PPs IAIN Syarif Hidayatullah, Jakarta, t.t.

Moeslichatoen, Metode Pengajaran di Taman Kanak-kanak, Jakarta, Rineka Cipta, 1999

Nata, Abuddin, Tafsir Ayat-ayat Pendidikan, Jakarta, PT. Raja Grafindo Persada, 2014

Rahmat, Jalaludin, Islam Aktual, Bandunng, Mizan, 1992

Shihab, Muhammad Quraish, Tafsir al-Misbah; Pesan, Kesan dan Keserasian al-Qur'an, Vol. 3, Jakarta, Lentera Hati, 2002

Soemanto, Wasty, Psikologi Pendidikan; Landasan Kerja Pemimpin Pendidikan, Jakarta, Rineka Cipta, 1998

Suryosubrata B., Beberapa Aspek Dasar Pendidikan, Jakarta, Bina Aksara, 1983

Yunus, Mahmud, Kamus Arab Indonesia, Jakarta, Yayasan Penyelenggara Penterjemah dan Pentafsir Al-Qur'an, 1973

Wehr, Hans, A Dictionary of Modern Written Arabic, Beirut, Librarydu Liban, 1974 